\title{
Regional patterns of kittiwake Rissa tridactyla breeding success are related to variability in sandeel recruitment
}

\author{
Morten Frederiksen ${ }^{1, *}$, Peter J. Wright ${ }^{2}$, Michael P. Harris ${ }^{1}$, Roderick A. Mavor ${ }^{3}$, \\ Martin Heubeck ${ }^{4}$, Sarah Wanless ${ }^{1}$ \\ ${ }^{1}$ Centre for Ecology and Hydrology, Hill of Brathens, Banchory, AB31 4BW, UK \\ ${ }^{2}$ FRS Marine Laboratory, PO Box 101, 375 Victoria Road, Aberdeen, AB11 9DB, UK \\ ${ }^{3}$ Joint Nature Conservation Committee, Dunnet House, 7 Thistle Place, Aberdeen, AB10 1UZ, UK \\ ${ }^{4}$ University of Aberdeen (SOTEAG), c/o East House, Sumburgh Head Lighthouse, Virkie, Shetland, ZE3 9JN, UK
}

\begin{abstract}
The population dynamics of marine top predators such as seabirds may be self-regulating through local prey depletion, or they may reflect environmentally induced fluctuations in prey availability. Both mechanisms are not mutually exclusive. We examined spatio-temporal variation in breeding success of black-legged kittiwakes Rissa tridactyla, a seabird widely monitored in the British Isles. Kittiwakes here feed mostly on lesser sandeels Ammodytes marinus, a species that is strongly tied to specific sediment types and therefore shows a strong regional population structure. Neither kittiwake colony growth rate nor breeding success correlated negatively with colony size as expected under local prey depletion in the absence of regional variation in carrying capacity. We used multivariate analyses of breeding success data for 42 kittiwake colonies to identify clusters showing synchronised variation in success, and compared these with known sandeel aggregations identified from fish and fishery surveys. A number of geographically distinct clusters of kittiwakes were identified, and these were largely congruent with sandeel aggregations. Major sandeel aggregations with clear associated clusters of kittiwake colonies occurred off of east England and east Scotland, while western coasts of Britain were characterised by smaller aggregations and less obvious kittiwake clusters. There was considerable regional variability in sandeel recruitment, and this was reflected in mostly uncorrelated time series of kittiwake breeding success between different regions. These results indicate that regional variation in prey availability had a stronger effect on kittiwake dynamics than local prey depletion. An appreciation of the appropriate spatial scale of prey dynamics thus improves understanding of the dynamics of marine predator - prey systems.
\end{abstract}

KEY WORDS: Kittiwakes - Sandeels - Spatial population dynamics - Population regulation · Rissa tridactyla $\cdot$ Ammodytes marinus

\section{INTRODUCTION}

One of the most important aspects of marine ecosystem function is the strength and direction of trophic interactions. For example, what is the functional relationship between top predator populations and their prey? Colonial top predators, such as seabirds, may cause local depletion of prey popu- lations and thus be self-regulating through densitydependent mechanisms (Birt et al. 1987). Alternatively, predator abundance and demographic performance (fecundity, survival) may be determined by the availability of their prey, which in turn may be regulated through density-dependent and/or densityindependent mechanisms related to environmental factors (Davoren \& Montevecchi 2003). While these 
mechanisms are not mutually exclusive, they have profoundly different implications, e.g. for the relative importance of top-down and bottom-up control and for what monitoring of predators can tell us about the state of the marine environment (Montevecchi 1993). Determining which of these mechanisms is most important is thus critical for understanding the role of marine top predators.

If predators cause local prey depletion and environmental effects on prey availability are less important, several simple predictions can be made about patterns of colony size and performance (e.g. Furness \& Birkhead 1984, Cairns 1989), and some of these patterns have been demonstrated. For example, Moss et al. (2002) demonstrated that small colonies of northern gannets Morus bassanus grew faster than large ones, and Lewis et al. (2001a) found for the same species that birds breeding in large colonies had a larger foraging range than birds from smaller colonies, although this could be an effect of prey disturbance rather than prey depletion. Similarly, Coulson (1983) found that between 1959 and 1969 large colonies of black-legged kittiwakes Rissa tridactyla in the British Isles grew more slowly than smaller colonies. In a rare study using direct measures of prey availability, Ainley et al. (2003) also found that the density of fish shoals decreased with colony size for black-legged kittiwakes in Alaska, indicating an effect of the birds on the dynamics of their prey. However, if spatio-temporal variation in prey availability is mainly determined by environmental effects, such simple patterns are unlikely to be found. Instead, colonies exploiting the same local prey population would be expected to show correlated patterns of annual variation in mean performance (e.g. breeding success), possibly leading to geographical clusters of colonies showing similar dynamics. Within such clusters some of the simple patterns which would be expected if predators deplete prey populations may still hold, but on a larger geographical scale they may be swamped by regional variation.

Few seabird species have been monitored on a sufficiently large geographical and temporal scale to allow exploration of these hypotheses. The blacklegged kittiwake (hereafter kittiwake) is the most widely monitored seabird in the British Isles, with population size and breeding success having been recorded in study plots in dozens of colonies throughout Britain and Ireland since 1986 (e.g. Mavor et al. 2003). Breeding populations on the British North Sea coast have declined by about $50 \%$ since the mid1980 s, and in Shetland by up to $70 \%$, whereas populations in Ireland and parts of northern and western Scotland have increased (Heubeck et al. 1999, Heubeck 2004). Year-to-year fluctuations in breeding success have also differed regionally within the British Isles, with complete failures occurring in Shetland (Mavor et al. 2003). In a preliminary study, Furness et al. (1996) showed that kittiwake colonies in the British Isles during 1986 to 1993 tended to form geographical clusters with similar annual fluctuations in breeding success.

In the western North Sea, breeding kittiwakes feed mainly on Ammodytes marinus, lesser sandeels, hereafter sandeels (Harris \& Wanless 1997, Furness \& Tasker 2000, Lewis et al. 2001b). Kittiwake diet has been less well studied elsewhere in Britain and Ireland and, although sandeels have been recorded in the diet at some colonies (e.g. Swann et al. 1991), other prey species may be important in areas such as the Irish Sea. Even within the North Sea, kittiwakes from some estuarine colonies feed mainly on clupeids rather than sandeels (Bull et al. 2004). Sandeels are closely associated with specific types of sandy sediment to which they settle as juveniles; they subsequently spend most of their life buried, except when feeding in the water column or spawning (Wright et al. 2000). Thus, they are found close to areas of suitable sediment throughout the year. Movements following settlement appear to be rather limited with virtually no dispersal between areas $>30 \mathrm{~km}$ apart (Gauld 1990). Sandeels are an important prey of kittiwakes, with predominantly Age 1 and older fish (1+ group) being taken during incubation and young of the year (0 group) during chick rearing (Wright 1996, Lewis et al. 2001b). Sandeels are the target of an important industrial fishery, and around the UK they are currently managed as 1 large North Sea stock and much smaller coastal stocks around Shetland and off the coast of northwestern Scotland (ICES 2003). However, within the North Sea there are several distinct spawning aggregations with limited movement between them (Proctor et al. 1998, Pedersen et al. 1999, Munk et al. 2002). The Shetland stock appears to be part of an aggregation which spawns around Orkney, and recruitment in Shetland is dependent on advection of larvae from Orkney (Wright 1996). Any differences in temporal population dynamics between these distinct sandeel aggregations could be an important factor affecting regional variation in kittiwake breeding success in areas where sandeels are the main prey. Kittiwakes in the British Isles are thus a suitable model system for testing whether the demographic performance of top predators is linked to geographical variation in prey availability since spatiotemporal variation in prey abundance is expected and sufficient data are available.

Here, we analyse data on kittiwake breeding success and sandeel population structure with the aim of (1) assessing the evidence for the prey depletion and regional variation hypotheses, (2) extending the 
approach of Furness et al. (1996) by grouping kittiwake colonies into geographically contiguous regions showing similar annual fluctuations in breeding success, and (3) assessing whether such regions are consistent with the available data on the geographical structure of sandeel aggregations.

\section{MATERIALS AND METHODS}

Kittiwake breeding success (number of fledged chicks/nest) has been monitored in a standardised way in Britain and Ireland annually since 1986 as part of the UK and Irish Seabird Monitoring Programme (SMP; Harris 1987, Mavor et al. 2003). About 90 colonies have been included in the survey, but to examine spatiotemporal patterns we restricted ourselves to data from 42 colonies surveyed in at least 10 years between 1986 and 2002 (Fig. 1, Table 1). Most colonies had 1 or more years with missing data, only 16 were surveyed in all 17 years. In total, 92 data points, i.e. colony-year combinations, were missing $(13 \%)$. Colony sizes in 1985-88 were taken from the Seabird Colony Register (SCR) survey (Lloyd et al. 1991) and in 1998-2002 from the Seabird 2000 survey (Mitchell et al. 2004). We examined correlations between population growth (from SCR to Seabird 2000) and colony size in the SCR survey, and also between colony size in the 2 surveys and mean breeding success in the respective years (1986-88 and 1998-2002).

The analysis of variation in kittiwake breeding success progressed in 3 steps. First, to concentrate on common patterns in year-to-year fluctuations we removed consistent differences among colonies and years. We fitted a generalized linear model (GLM) to the data with main year, colony effects, and a log link function weighted by annual sample size (number of nests monitored). The residuals from this model contained all the information on regional synchrony; they were normally distributed (see 'Results'), and we used them in further analyses. Because the multivariate methods used do not accept missing values, we imputed the missing data. Simple imputation does not bias parameter estimates, but it leads to artificially low variance estimates and too narrow confidence intervals. We therefore used multiple imputation (SAS Institute Inc. 2001), which provides a range of normally distributed likely values for missing data points allowing unbiased variance estimates. We used 5 values for each missing data point, and these values were then used as replicate data points in the subsequent step. Second, we used principal component analysis $(\mathrm{PCA})$ on the $210(5 \times 42)$ by 17 data matrix. Mean principal component scores and their standard deviations were calculated from the 5 replicates for the
26 colonies with missing data. Cluster analysis with Ward's minimum-variance method (SAS Institute Inc. 1999) was employed to further investigate spatial structure, using means of the 5 imputed values for missing data points. Regions showing homogeneous variation over time were identified informally by combining the results of these analyses with geographical location. Third, we checked the validity of these regions by fitting a GLM with main region and year effects, and their interaction, to the original data, and compared the performance of the suggested regions to the classification used in the SMP. We used Akaike's Information Criterion (AIC; Burnham \& Anderson 1998) to determine which of the 2 classifications was most parsimonious; a low AIC value indicates a more parsimonious model. Within each region, we calcu-

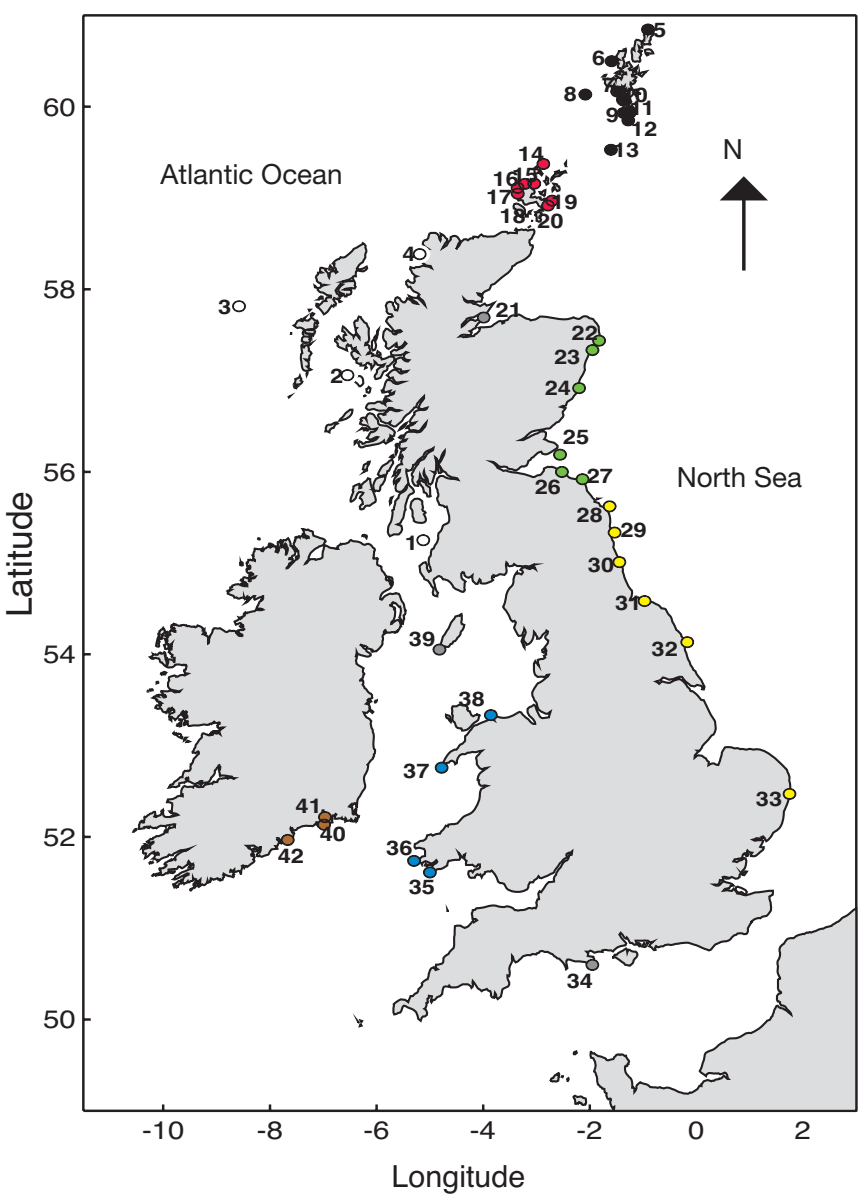

Fig. 1. Locations of the 42 colonies where kittiwake Rissa tridactyla breeding success was monitored in at least 10 years during 1986-2002 (see also Table 1). Colours refer to the regions used in the Seabird Monitoring Programme: Shetland (black), Orkney (red), northeast and southeast Scotland (green), northeast and east England (yellow), Wales (blue), southeast Ireland (brown), and southwest and northwest Scotland (white). Grey symbols indicate regions represented by only 1 colony (north Scotland, southwest England and northwest England (see also Table 1) 
Table 1. List of the 42 Rissa tridactyla study colonies showing their regional affiliation under the SMP scheme and our proposed scheme, as well as the closest sandeel aggregation. The number of years with available data on kittiwake breeding success during 1986-2002 are also shown

\begin{tabular}{|c|c|c|c|}
\hline $\begin{array}{l}\text { SMP region } \\
\text { Proposed region }\end{array}$ & $\begin{array}{l}\text { Sandeel } \\
\text { aggregation }\end{array}$ & Colony & $\begin{array}{l}\text { Years } \\
\text { of data }\end{array}$ \\
\hline \multicolumn{4}{|l|}{ SW Scotland } \\
\hline Irish Sea & - & 1 Ailsa Craig & 16 \\
\hline \multicolumn{4}{|l|}{ NW Scotland } \\
\hline \multirow[t]{3}{*}{ W Scotland } & Western Isles & 2 Canna & 17 \\
\hline & - & 3 St Kilda & 16 \\
\hline & Western Isles & 4 Handa & 16 \\
\hline \multicolumn{4}{|l|}{ Shetland } \\
\hline \multirow[t]{9}{*}{ Shetland } & Shetland & 5 Hermaness & 14 \\
\hline & & 6 Eshaness & 14 \\
\hline & & 7 Westerwick & 17 \\
\hline & & 8 Foula & 17 \\
\hline & & 9 Noss & 17 \\
\hline & & 10 Ramna Geo & 10 \\
\hline & & 11 Troswick Ness & 10 \\
\hline & & 12 Sumburgh Head & 17 \\
\hline & & 13 Fair Isle & 17 \\
\hline \multicolumn{4}{|l|}{ Orkney } \\
\hline \multirow[t]{7}{*}{ Orkney } & Orkney & 14 Papa Westray & 14 \\
\hline & & 15 Rousay & 14 \\
\hline & & 16 Costa Head & 10 \\
\hline & & 17 Marwick Head & 17 \\
\hline & & 18 Row Head & 17 \\
\hline & & 19 Mull Head & 17 \\
\hline & & 20 Gultak & 17 \\
\hline \multicolumn{4}{|l|}{ N Scotland } \\
\hline- & Moray Firth & 21 North Sutor & 13 \\
\hline \multicolumn{4}{|l|}{ NE Scotland } \\
\hline \multirow[t]{3}{*}{ E Scotland } & E Scotland & 22 Bullers of Buchan & 13 \\
\hline & & 23 Sands of Forvie & 13 \\
\hline & & 24 Fowlsheugh & 15 \\
\hline \multicolumn{4}{|l|}{ SE Scotland } \\
\hline \multirow[t]{3}{*}{ E Scotland } & E Scotland & 25 Isle of May & 17 \\
\hline & & 26 Dunbar & 16 \\
\hline & & 27 St Abb's Head & 16 \\
\hline \multicolumn{4}{|l|}{ NE England } \\
\hline E Scotland & E Scotland & 28 Farne Islands & 16 \\
\hline \multirow[t]{4}{*}{ E England } & E Scotland & 29 Coquet Island & 10 \\
\hline & E England & 30 North Shields & 17 \\
\hline & E England & 31 Saltburn & 17 \\
\hline & E England & 32 Bempton & 16 \\
\hline \multicolumn{4}{|l|}{ E England } \\
\hline E England & E England & 33 Lowestoft & 17 \\
\hline \multicolumn{4}{|l|}{ SW England } \\
\hline- & - & 34 Durlston Head & 12 \\
\hline \multicolumn{4}{|l|}{ Wales } \\
\hline \multirow[t]{4}{*}{ Irish Sea } & Irish Sea & 35 Elegug Stacks & 12 \\
\hline & & 36 Skomer & 17 \\
\hline & & 37 Bardsey & 15 \\
\hline & & 38 Great Ormes Head & d 14 \\
\hline \multicolumn{4}{|l|}{ NW England } \\
\hline Irish Sea & Irish Sea & 39 Calf of Man & 10 \\
\hline SE Ireland & & & \\
\hline Irish Sea & Irish Sea & 40 Dunmore East & 17 \\
\hline & & 41 Portally & 15 \\
\hline & & 42 Ram Head & 10 \\
\hline
\end{tabular}

lated the amount of variation explained by a GLM with only year effects, as well as all between-colony correlations, again based on original data. Finally, we calculated weighted annual least-squares mean breeding success for our regions, as well as associated betweenregion correlations. All statistical calculations were carried out in SAS 8.2 (SAS Institute Inc. 1999, 2001).

Information on sandeel distribution was extracted from fishery research surveys of the larvae and post-settled stages. The eggs of sandeels are demersal and newly emerged larvae will thus not have had much time to be dispersed, so spawning areas were defined using the distribution of newly emerged sandeel larvae (Proctor et al. 1998). The densities of larvae provide an indication of the relative size of spawning components. Additional information on distribution was derived from the occurrence of post-settled sandeels in bottom sampling gear, including light bottom trawls, dredges and records of enmeshment in regular ICES-coordinated bottom trawl surveys (sources listed in 'Acknowledgements'). Due to the different types of gear employed and the extensive period over which sampling took place (1970-2002), these data only show presence or absence of sandeels. The data provide coverage of the region 61 to $53^{\circ} \mathrm{N}$ and $09^{\circ} \mathrm{W}$ to $3^{\circ} \mathrm{E}$. Mean larval density, post-settled sandeel occurrence and kittiwake colony location were projected onto a common $0.25^{\circ}$ latitude by $0.5^{\circ}$ longitude grid ( 15 nautical miles $\left.{ }^{2}\right)$ in a planar projection in the GIS package IDRISI 32 (www.clarklabs.org). Distances between kittiwake colonies and sandeels were then estimated using the spherical distance analysis function, and colonies were assigned to the nearest sandeel aggregation.

\section{RESULTS}

There was a weak negative correlation between colony growth rate (expressed as the logarithm of the ratio of the Seabird 2000 count to the SCR count) and the log-transformed SCR count (Fig. 2, $\mathrm{r}=-0.249, \mathrm{n}=42, \mathrm{p}=0.11$ ), but this result was strongly affected by the initially smallest colony (Coquet) growing very rapidly (without Coquet: $\mathrm{r}=-0.054, \mathrm{n}=41, \mathrm{p}=0.74$ ). There was no significant correlation between log-transformed colony size and breeding success either for the SCR census $(r=0.055, n=$ 
$30, p=0.78)$ or the Seabird 2000 census $(r=0.144, n=$ $40, \mathrm{p}=0.37$ ).

The GLM with main year and colony effects explained $48 \%$ of the total variance in breeding success, and the residuals were normally distributed (Shapiro-Wilk test, $\mathrm{p}>0.05$ ). The 2 first principal components calculated from these residuals together accounted for $40 \%$ of the remaining variation, and a plot of these 2 components indicated some informative clusters (Orkney, Shetland, east England, east Scotland; Fig. 3). PC1 (23\%) contrasted colonies doing relatively well during the 1990s (e.g. Shetland) with those doing relatively well in the late 1980s and early 2000s (e.g. east Scotland), whereas the interpretation of PC2 $(17 \%)$ was less obvious. In the cluster analysis, where all the information in the residuals was used, these patterns were still apparent (Fig. 4). However, some colonies unexpectedly clustered with those from other regions: Eshaness (Colony 6 in Fig. 1 and Table 1) in Shetland and the Farne Islands (Colony 28, the northernmost colony in eastern England) were similar to the east Scotland colonies (this was also apparent from the PCA; Fig. 3). Ailsa Craig (Colony 1), the southernmost colony in west Scotland, clustered with several Welsh colonies (Fig. 4). Colonies in Wales and southeast Ireland tended to group together, forming a loose Irish Sea cluster. Since our aim was to identify regions which were both geographically and biologically meaningful, we considered it inappropriate to include distant colonies in the same region (e.g. including Eshaness with east Scotland). On the basis of PCA and cluster analysis results, as well as geographical considerations, we propose the following regions to provide an informative summary of geographical variation in kittiwake breeding success, presumably related to variation in food availability: (1) Shetland, (2) Orkney, (3) east Scotland (including Farne Islands), (4) east England (excluding Farne Islands), (5) Irish Sea (Wales, southeast Ireland, Calf of Man, including Ailsa Craig), and (6) west Scotland (excluding Ailsa Craig). The first 4 of these regions are well defined geographically and formed distinct clusters (Figs. 3 \& 4), whereas the remaining 2 were less distinct. We included Eshaness with the Shetland cluster, but 2 colonies could not be assigned to clusters (North Sutor in the Moray Firth [Colony 21] and Durlston Head in Dorset [Colony 34]). Calf of Man (Colony 39) was also difficult to assign (Fig. 4), but based on geographical criteria we included it in the loose Irish Sea cluster.

We compared our proposed classification to the 13 regions currently used in the SMP (Table 2). Although the SMP classification explained a larger proportion of the variation, it did so with a much larger number of parameters, and our classification was statistically more parsimonious. We also checked the internal consistency

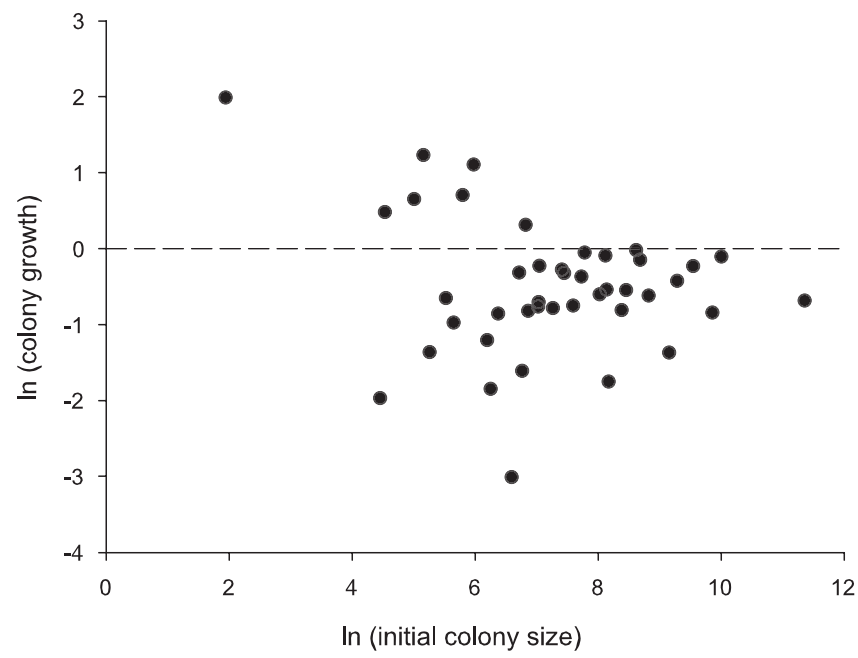

Fig. 2. Rissa tridactyla. Relationship between initial colony size (log-transformed) and colony growth (log-transformed ratio of final to initial colony size) from the Seabird Colony Register survey in 1985-1988 to the Seabird 2000 survey in 1998-2002, for the 42 study colonies. Of the 42 colonies, 35 declined in size over this period, but large colonies did not decline more rapidly than small ones (see 'Results')

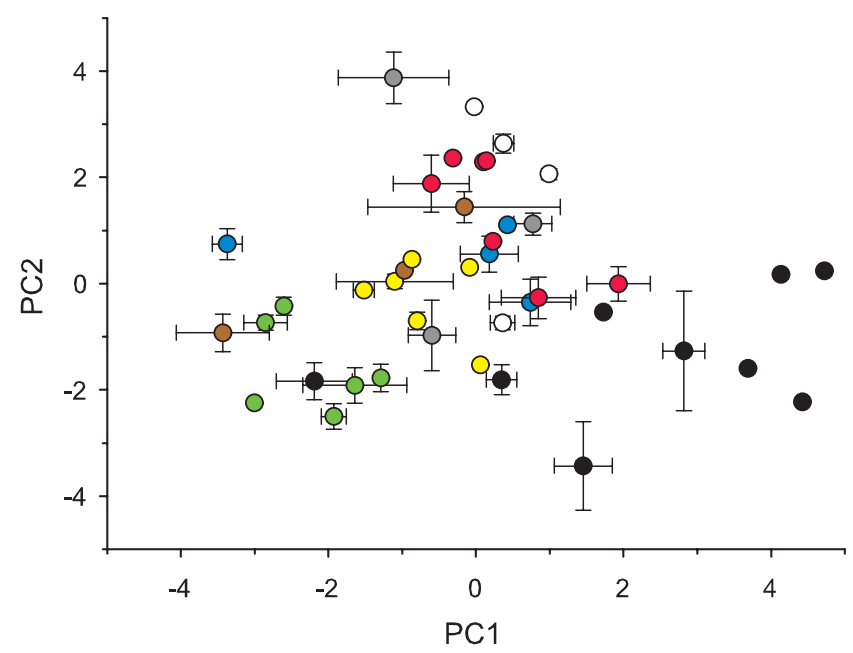

Fig. 3. Rissa tridactyla. The 42 study colonies plotted according to the first 2 principal components of spatiotemporal variation in breeding success. The 2 axes explain $40 \%$ of the total variation. Colours refer to the SMP regions as defined in Fig. 1

of our regions and found that the Shetland, east Scotland and east England regions were very consistent (Table 3); a model with only year effects explained $>50 \%$ of the within-region variation, and most or all among-colony correlations were positive, with many being statistically significant. Orkney was also reasonably consistent, although less variation was explained and fewer between-colony correlations were significant, while the Irish Sea and west Scotland clusters performed less well. The inclusion of Calf of Man in the Irish Sea cluster was 


$\begin{array}{ll}\text { Eshaness } & 1 \\ \text { Dunbar } & 3 \\ \text { Fowlsheugh } & 3 \\ \text { Sands of Forvie } & 3 \\ \text { Bullers of Buchan } & 3 \\ \text { Farne Islands } & 4 \\ \text { St Abb's Head } & 3 \\ \text { Isle of May } & 3 \\ \text { Hermaness } & 1 \\ \text { Papa Westray } & 2 \\ \text { Rousay } & 2 \\ \text { Coquet Island } & 4 \\ \text { Lowstoft } & 4 \\ \text { Saltburn } & 4 \\ \text { Calf of Man } & \\ \text { St Kilda } & 7 \\ \text { Bempton } & 4 \\ \text { North Shields } & 4 \\ \text { Dunmore East } & 6 \\ \text { Skomer } & 5 \\ \text { Ram Head } & 6 \\ \text { North Sutor } & 6 \\ \text { Portally } & 2 \\ \text { Costa Head } & 2 \\ \text { Marwick Head } & 2 \\ \text { Row Head } & 2 \\ \text { Gultak } & 2 \\ \text { Mull Head } & 2 \\ \text { Durlston Head } & 7 \\ \text { Canna } & 7 \\ \text { Handa } & 1 \\ \text { Fair Isle } & 1 \\ \text { Sumburgh Head } & 1 \\ \text { Troswick Ness } & 1 \\ \text { Foula } & 1 \\ \text { Westerwick } & 1 \\ \text { Noss } & 1 \\ \text { Ramna Geo } & 1 \\ \text { Elegug Stacks } & 5 \\ \text { Great Ormes Head } & 5 \\ \text { Ailsa Craig } & 7 \\ \text { Bardsey } & 5 \\ & \end{array}$

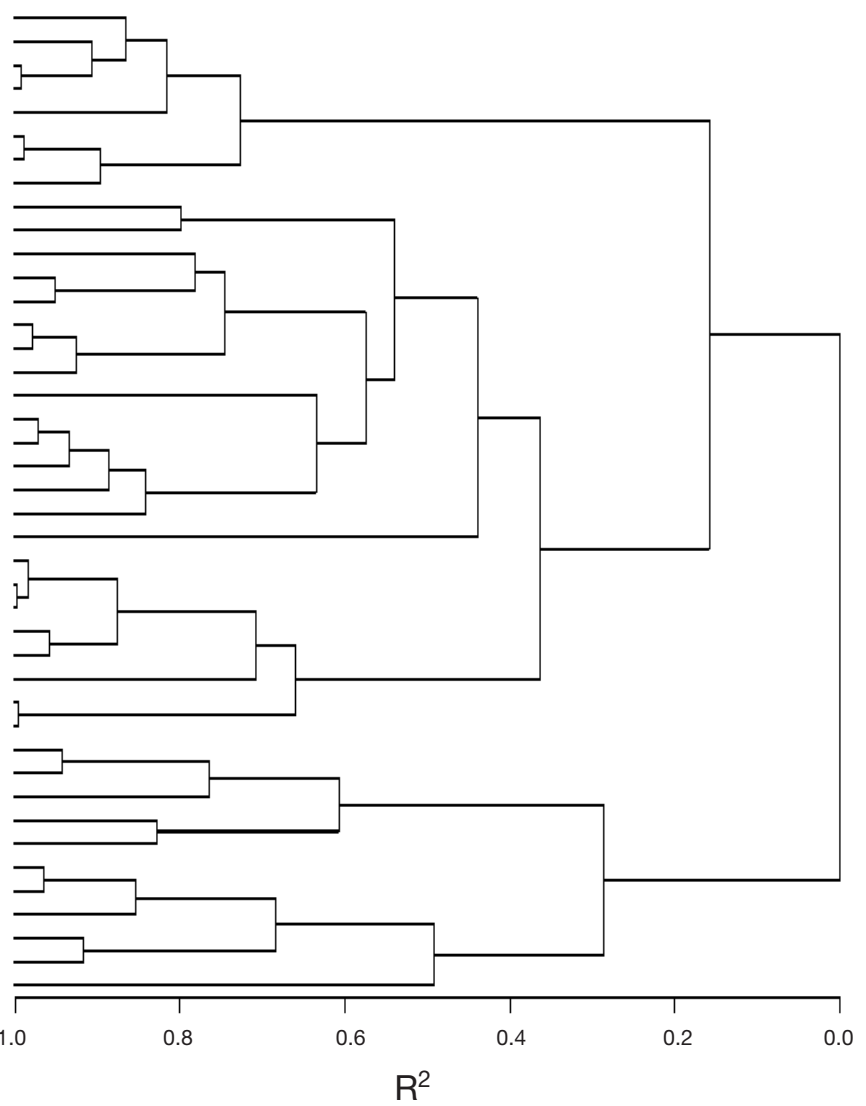

Fig. 4. Rissa tridactyla. Tree diagram showing results of the cluster analysis of spatiotemporal variation in $R$. tridactyla breeding success. Numbers refer to the SMP regions: 1 = Shetland, $2=$ Orkney, 3 = northeast and southeast Scotland, $4=$ northeast and east England, $5=$ Wales, $6=$ southeast Ireland, $7=$ southwest and northwest Scotland. No number indicates regions only represented by 1 colony; see also Table 1 densities occur off the Western and Northern Isles, the Scottish east coast firths and east England. High densities of larvae were not present between the concentrations off the east of England and Scotland, a distance of over $200 \mathrm{~km}$. Larval concentrations were contiguous between Shetland and Orkney, but less so between Orkney and east Scotland. The distribution of post-settled sandeels (Fig. 6b) indicated similar aggregations to the larval data. However, aggregations to the east of England and Scotland were more extensive than the density of larvae indicated. Nevertheless, postsettled sandeels were not contiguous between these 2 regions, the nearest sites being $>80 \mathrm{~km}$ apart. Data for the Scottish west coast and Irish Sea indicated that the aggregations in this region were more widely distributed and less extensive than in the North Sea. Survey coverage was highest in the northern North Sea (Fig. 6B) and it is possible that there are small areas with sandeels outside the surveyed area that are important to kittiwake colonies.

again questionable, as breeding success was negatively correlated with all 8 other colonies in the cluster, in 1 case (Great Ormes Head, Colony 38) significantly so. In total, $80 \%(102 / 127)$ of all within-region correlations were positive (vs. $54 \%$ [399/734] between regions, $\chi^{2}{ }_{1}=$ $30, \mathrm{p}<0.0001)$, and $49 \%(50 / 102)$ of these were significant at $\alpha=0.05$ (vs. $9 \%$ [37/399] between regions, $\chi^{2}{ }_{1}=$ 89, $\mathrm{p}<0.0001$; Table 3 ), indicating that the suggested regions provide a useful summary of regional variation in kittiwake breeding success.

Patterns of annual variation in breeding success differed widely among the regions (Fig. 5), and in only 1 case was there a significant correlation between them (Orkney and Shetland, Table 4). There was a tendency for a negative correlation between east and west Scotland, and breeding success in the Irish Sea seemed not to be correlated with any of the other regions (Table 4).

Sandeel spawning areas, as indicated by the density distribution of early larvae, are presented in Fig. 6A. The surveyed area provides good coverage for most of the North Sea and the Scottish west coast. The major
In most cases, the geographical grouping of kittiwake colonies (based on variation in breeding success) corresponded with the spatial segregation of sandeels. For example, kittiwake colonies along the east coast of Scotland, which showed very similar fluctuations in breeding success (Table 3), shared a network of sandeel patches extending from the Farne Islands to just south of the Moray Firth (referred to as east Scotland in Table 1 and Fig. 6C). Some uncertainties in the classification based on breeding success also reflected the distribution of sandeel aggregations. For example, kittiwakes from North Sutor in the Moray Firth (Colony 21), which was not included in any obvious cluster (Fig. 4), may be expected to forage on an aggregation not shared with other study colonies (see Fig. 6B). Similarly, the sandeel aggregation near the Calf of Man (Colony 39) is geographically isolated from those on the Welsh and Irish coasts. Furthermore, the small isolated sandeel aggregations to the west of Scotland and in the Irish Sea may explain the weaker correlations in breeding success among colonies in these 2 regions. 


\section{DISCUSSION}

There was little evidence of the patterns expected if density-dependent regulation through local food depletion was the dominant process in the kittiwakesandeel system. Small colonies did not grow faster than large ones (Fig. 2), and there was no negative relationship between colony size and breeding success. On the other hand, there was substantial evidence for consistent regional variation in kittiwake breeding success. Colonies within regions tended to show correlated fluctuations in breeding success (Figs. 2 \& 3, Table 3), whereas these patterns differed among regions (Fig. 5, Table 4).

Initially, our results seemed to contradict the hypothesis that the size and productivity of seabird colonies is regulated by density-dependence working through local prey depletion or reduced availability through interference (e.g. Furness \& Birkhead 1984, Lewis et al. 2001a, Ainley et al. 2003). However, simple patterns confirming this hypothesis are only expected if carrying capacity per areal unit is the same everywhere, or in other words, if prey availability is constant or shows highly correlated annual fluctuations over space. If the main prey exhibits a strong spatial population struc-

Table 2. Performance of the proposed regional groupings of Rissa tridactyla colonies, compared to those used in the SMP, in explaining spatio-temporal variation in breeding success in 42 colonies 1986-2002 ( $\mathrm{n}=622$ colony-years). $\mathrm{R}^{2}$, deviance (-2 log likelihood), number of parameters (np) and Akaike's Information Criterion (AIC) are shown for GLM models with region, year effects, and their interaction

\begin{tabular}{|lcccc|}
\hline Model & $\mathrm{R}^{2}$ & Deviance & $\mathrm{np}$ & $\mathrm{AIC}$ \\
\hline $\begin{array}{l}\text { Proposed scheme (6 regions } \\
\text { plus 2 single colonies) }\end{array}$ & $58.7 \%$ & 255.10 & 127 & 509.10 \\
SMP scheme (13 regions) & $65.4 \%$ & 144.52 & 209 & 562.52 \\
\hline
\end{tabular}

Table 3. Performance of the 6 proposed regions in explaining within-region spatio-temporal variation in Rissa tridactyla breeding success. Shown for each region are the number of colonies included (n), $\mathrm{R}^{2}$ of a GLM with year effect only, and the number of positive correlations between colonies within each region (among all correlations or only those significant at $\alpha=0.05$ ). For comparison, the same results are shown for the entire dataset without regional division

\begin{tabular}{|lcccc|}
\hline Region & $\mathrm{n}$ & $\begin{array}{r}\mathrm{R}^{2} \\
\%\end{array}$ & $\begin{array}{c}\text { All correlations } \\
\text { (positive/all) }\end{array}$ & $\begin{array}{c}\text { Significant correlations } \\
\text { (positive/all) }\end{array}$ \\
\hline Shetland & 9 & 58.9 & $30 / 36$ & $19 / 19$ \\
Orkney & 7 & 30.6 & $17 / 21$ & $3 / 3$ \\
E Scotland & 7 & 63.5 & $21 / 21$ & $19 / 19$ \\
E England & 5 & 51.2 & $10 / 10$ & $4 / 4$ \\
Irish Sea & 9 & 33.3 & $22 / 36$ & $4 / 5$ \\
W Scotland & 3 & 17.2 & $2 / 3$ & $1 / 1$ \\
All within-region & & & $102 / 127$ & $50 / 51$ \\
All colonies & 42 & 10.6 & $501 / 861$ & $87 / 110$ \\
\hline
\end{tabular}

ture, with local populations having non-synchronous ariation in abundance or productivity, these patterns the more local scale, for example, w defined here for kittiwakes. We tested for correlations between colony size and population growth rate or breeding success within the regions defined here; only in east England was there a significant negative etween initial colony size and growth rate -0.937, $\mathrm{n}=5, \mathrm{p}=0.019$; other results not shown). Thus, while there was considerable evidence for regu(see of local prey depletion or interference effects. Using data from a set of colonies with a very similar geographical coverage to ours, Coulson (1983) found a strong negative correlation between initial colony size and population growth rate in British kittiwakes during a phase of rapid expansion (1959-1969). The reasons for this difference are difficult to establish retrospectively, but one can speculate for instance that prey availability was spatially more uniform then than now, or that kittiwake behavioural processes (Danchin et al. 1998) had a stronger effect on spatial patterns of recruitment when populations were smaller and food possibly superabundant.

The regional structure used to summarise kittiwake breeding success in the SMP (e.g. Mavor et al. 2003) was biologically well founded and accounted for much of the observed geographical variation (Table 2), although we propose some adjustments. Shetland and Orkney appeared as natural clusters. Distinguishing between northeast and southeast Scotland, as well as between northeast and eastern England, seemed unnecessary, but the northernmost English colony, the Farne Islands, was better included with eastern Scotland. There was some similarity between colonies around the Irish Sea (Wales, southeast Ireland, southwest Scotland), although this cluster was not very clear and the grouping of Calf of Man with neighbouring colonies was questionable. The few colonies monitored in western Scotland showed great variation in patterns. While much of the inter-colony variation in breeding success could be related to sandeel 

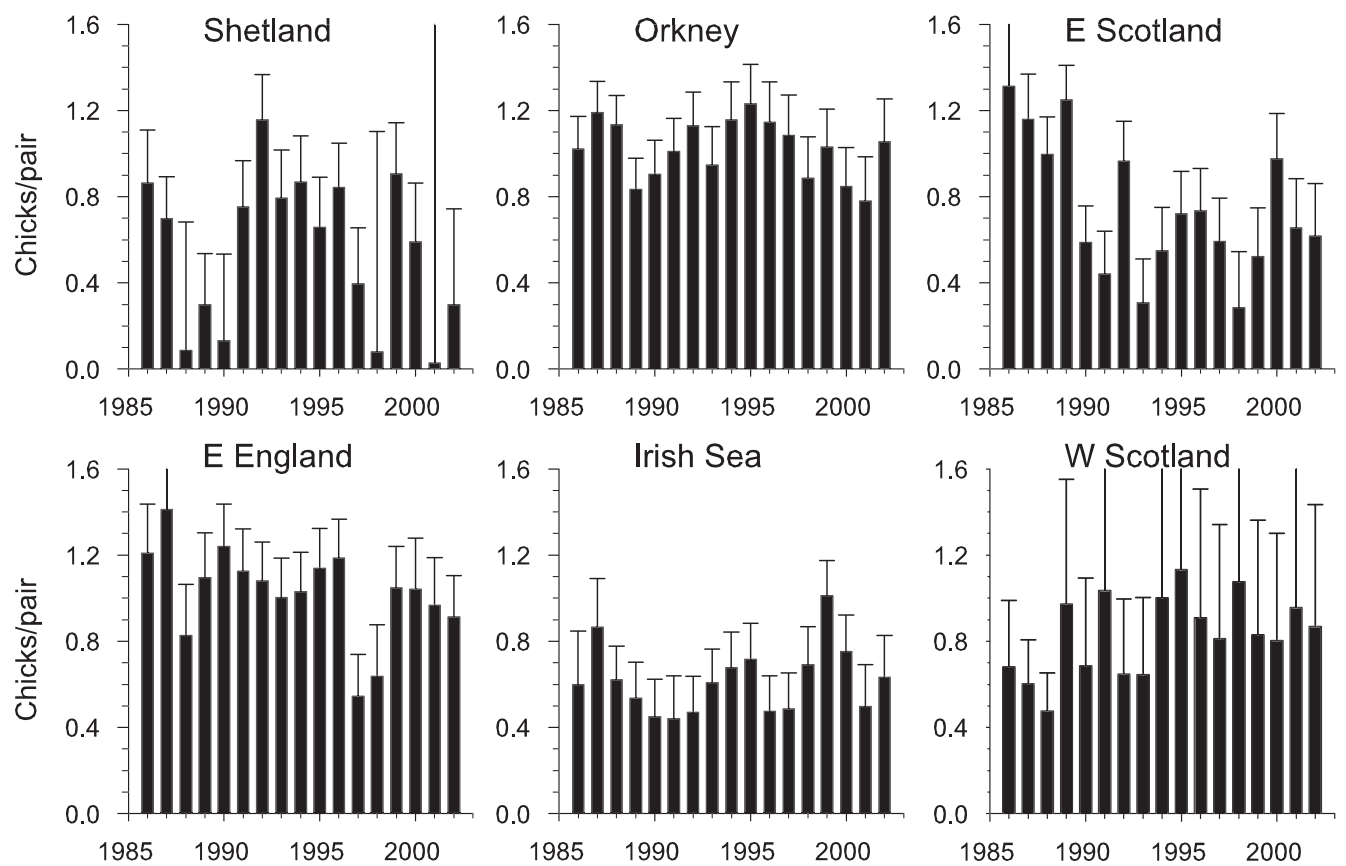

Fig. 5. Rissa tridactyla. Temporal variation in breeding success in the 6 proposed regions. Values shown are leastsquares means with $95 \%$ confidence limits

population structure (see below), other factors could also be important in some cases. The most likely explanation for the lack of correlation between Eshaness and other Shetland colonies is that between 1988 and 1990, when kittiwakes (and other seabirds) in most Shetland colonies had very low breeding success due to low availability of sandeels (Fig. 5), this colony was just within foraging range of a whitefish fishery, and by feeding on discards, Eshaness kittiwakes maintained a reasonable breeding success (M. Heubeck unpubl. data). Colony-specific predation, mainly by great skuas Catharacta skua, is also likely to have caused differences in breeding success unrelated to food supply (Heubeck et al. 1997), and factors such as these would tend to blur the patterns induced by regional variation in prey availability.

The distribution of early sandeel larvae indicated a number of geographically discrete spawning areas. Moreover, as early larvae will have been subject to some

Table 4. Rissa tridactyla. Correlations between annual least-squares mean breeding success in the 6 proposed regions (Fig. 5). Value in bold is significant at $\alpha=0.05$

\begin{tabular}{|lrrrrr|}
\hline & Shetland & Orkney & E Scotland & E England & Irish Sea \\
\hline Orkney & $\mathbf{0 . 5 0 5}$ & & & & \\
E Scotland & 0.119 & 0.112 & & & \\
E England & 0.449 & 0.185 & 0.442 & & \\
Irish Sea & 0.196 & 0.196 & 0.037 & 0.118 & \\
W Scotland & -0.081 & -0.140 & -0.396 & -0.160 & -0.039 \\
\hline
\end{tabular}

dispersal and advection from their spawning areas before sampling, the larval distributions presented in Fig. 6A are likely to overestimate the extent of important spawning areas. This is particularly likely in the region between Orkney and Shetland, where the Fair Isle current leads to rapid advection eastwards from the region (Turrell 1992). Model simulations of larval transport indicate that there is little exchange of larvae among the major spawning concentrations reported in this study (Proctor et al. 1998). In the North Sea, passive transport of larvae between these spawning areas is probably constrained by the frontal zones between freshwaterinfluenced water masses and the shelf water of the central North Sea (Munk et al. 2002). As the maximum recorded dispersal of post-settled sandeels is $64 \mathrm{~km}$ (Gauld 1990), the geographical isolation of many aggregations reported here is likely to reflect reproductive isolation. Regional differences in year-class strength are consistent with this proposed pattern of isolation. For example, whilst the 1996 year-class was very large off eastern England (Pedersen et al. 1999), it was less so off east Scotland and around Shetland (Rindorf et al. 2000, ICES 2003). Of all the regions, Shetland has experienced the greatest inter-annual variation, with sustained periods of low recruitment in the late 1980s and since 2000 (ICES 2003). These recruitment failures were clearly reflected in the breeding success of Shetland kittiwakes (Fig. 5). 
Regional differences in the dynamics of sandeel aggregations are also reflected in changes in fishing pattern. The aggregation off east England has sustained large landings since the fishery began in 1952 (Macer 1966), whilst that off east Scotland did not commence until the 1980s, with landings peaking in the early 1990s (ICES 2003). The Shetland fishery began in 1974, peaked in 1982, and was closed in 1990 due to a stock collapse (Wright 1996), re-opening in 1995 under a local precautionary management regime. The west coast fishery began in 1981 and peaked in 1986, and both effort and landings have now declined considerably (ICES 2003).

The low correlations between breeding success in the proposed regions (Table 4) indicate that the factors responsible for the fluctuations varied asynchronously among regions. Given that sandeel abundance can be a major factor influencing kittiwake breeding success (Wright 1996, Lewis et al. 2001b), regional variability in sandeel recruitment is a plausible explanation for the low correlation between breeding success among the proposed regions, at least in the North Sea. Indeed, the only 2 regions where a significant positive correlation was found (Shetland and Orkney) would also be expected to covary based on sandeel population dynamics, since the sandeel stock around Shetland depends on advection of larvae from the Orkney spawning grounds (Wright 1996, Proctor et al. 1998). When this advection failed, as in the late 1980s, more or less complete breeding failures of kittiwakes occurred in Shetland (Fig. 5).

Patterns in ecology often depend on the spatial scale of observation (Wiens 1989), and a full understanding of regional variation in the dynamics of predator populations thus requires an appreciation of the spatial scale of the main prey. In contrast to some other forage fish species, the unusual habitat association and limited dispersal of sandeels leads to substantial differences in recruitment within the North Sea and off the west coast of Scotland. It is therefore unsurprising that sandeel-dependent predators, particularly kittiwakes that have a limited foraging range and cannot exploit prey throughout the water column (Furness \& Tasker 2000), also show large regional variation in demographic performance and population dynamics. Sandeel recruitment appears influenced by the match with the onset of secondary production (Wright \& Bailey 1996) and variability in sea circulation (Proctor

Fig. 6. Ammodytes marinus. Distribution of sandeel aggregations around the British Isles based on (A) spawning areas and (B) presence of post-settled sandeels. Values in (A) refer to average numbers of larvae per $\mathrm{m}^{2}$ (for further details see Proctor et al. 1998). Values in (B) refer to present, absent or not sampled. Main aggregation areas are given in (C)
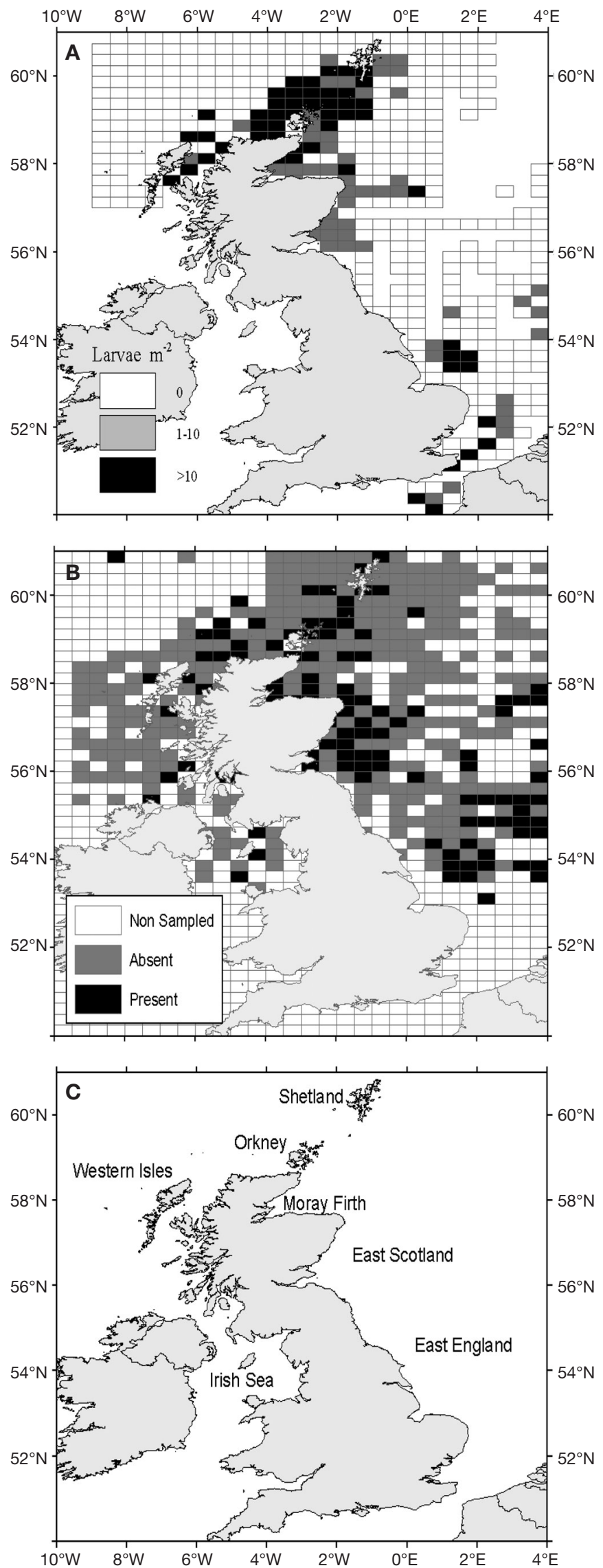
et al. 1998). Regional variability in the timing of production and advective losses from sandeel aggregations may therefore have an impact on the availability of this key prey to local kittiwake colonies. Many British kittiwake populations have declined sharply since about 1990 (Heubeck 2004); in 1 area the decline was related to the industrial sandeel fishery and increasingly warm winters, both effects probably mediated through sandeel availability (Frederiksen et al. 2004). However, it is currently unclear how far this result can be generalised.

We show here that the spatio-temporal dynamics of the kittiwake/sandeel system around the British Isles cannot be described by simple predictions from the prey depletion hypothesis. A full understanding of how breeding success varies over space and time would have to take several factors into account. Patchiness and non-synchronous dynamics of prey populations, partly caused by spatio-temporal variation in the physical environment, would lead to regional variation in breeding success fluctuations. Within regions defined by prey patches, local depletion or disturbance effects could still cause density-dependent regulation of breeding success, and potentially, colony size. At the same time, fisheries and other human impacts could also affect prey abundance and availability, and depending on the scale of these impacts, this could either synchronise or desynchronise regional predator dynamics. All these factors would need to be taken into account when, for instance, evaluating the utility of seabird breeding success for monitoring prey populations. While our findings are specific to the kittiwakesandeel system, we consider it likely that this situation also applies in other systems where a widespread predator relies on a prey showing strong regional variation in dynamics. Unfortunately, due to differences in the way sandeel stock abundance is assessed (ICES 2003) and, until recently, the limited monitoring of regional components of the North Sea stock (Pedersen et al. 1999), a detailed exploration of the relationship between the local abundance of sandeels and the performance of kittiwakes in the same area is not currently possible. More widespread sampling of kittiwake diet would also allow regions to be defined where sandeels are not the main prey and where kittiwake breeding success is therefore expected to be related to the availability of prey other than sandeels.

Acknowledgements. We are grateful to everyone who collected kittiwake breeding success data as part of the Seabird Monitoring Programme, coordinated by the Joint Nature Conservation Committee in partnership with the Shetland Oil Terminal Environmental Advisory Group and the Royal Society for the Protection of Birds. Thanks to D. Elston for useful statistical advice, to I. Gibb for producing the maps, and to I. Mitchell and 4 anonymous referees for valu- able comments. Data on sandeels were collated as part of contract CFP 98/025 from the Commission of the European Communities; data were supplied by the Scottish Fishery Protection Board, the Scottish Groundfish Survey, FRS (Shetland surveys, acoustic surveys, exploratory sandeel fishing surveys), and CEFAS (sandeel survey).

\section{LITERATURE CITED}

Ainley DG, Ford RG, Brown ED, Suryan RM, Irons DB (2003) Prey resources, competition, and geographic structure of Kittiwake colonies in Prince William Sound. Ecology 84: 709-723

Birt VL, Birt TP, Goulet D, Cairns DK, Montevecchi WA (1987) Ashmole's halo: direct evidence for prey depletion by a seabird. Mar Ecol Prog Ser 40:205-208

Bull J, Wanless S, Elston DA, Daunt F, Lewis S, Harris MP (2004) Local-scale variability in the diet of black-legged kittiwakes Rissa tridactyla. Ardea 92:43-52

Burnham KP, Anderson DR (1998) Model selection and inference: a practical information-theoretic approach. Springer, New York

Cairns DK (1989) The regulation of seabird colony size: a hinterland model. Am Nat 134:141-146

Coulson JC (1983) The changing status of the Kittiwake Rissa tridactyla in the British Isles, 1969-1979. Bird Study 30: 9-16

Danchin E, Boulinier T, Massot M (1998) Conspecific reproductive success and breeding habitat selection: implications for the study of coloniality. Ecology 79:2415-2428

Davoren GK, Montevecchi WA (2003) Signals from seabirds indicate changing biology of capelin stocks. Mar Ecol Prog Ser 258:253-261

Frederiksen M, Wanless S, Harris MP, Rothery P, Wilson LJ (2004) The role of industrial fisheries and oceanographic change in the decline of North Sea black-legged kittiwakes. J Appl Ecol 41:1129-1139

Furness RW, Birkhead TR (1984) Seabird colony distributions suggest competition for food supplies during the breeding season. Nature 311:655-656

Furness RW, Tasker ML (2000) Seabird-fishery interactions: quantifying the sensitivity of seabirds to reductions in sandeel abundance, and identification of key areas for sensitive seabirds in the North Sea. Mar Ecol Prog Ser 202: $253-264$

Furness RW, Greenstreet SPR, Walsh PM (1996) Spatial and temporal variability in the breeding success of seabirds around the British Isles: evidence for distinct sandeel stocks? In: Hunt GL, Furness RW (eds) Seabird/fish interactions, with particular reference to seabirds in the North Sea. ICES Cooperative Research Report No. 216. International Council for the Exploration of the Sea, Copenhagen, p 63-65

Gauld JA (1990) Movements of lesser sandeels (Ammodytes marinus Raitt) tagged in the northwestern North Sea. J Conseil 46:229-231

Harris MP (1987) A low-input method of monitoring kittiwake Rissa tridactyla breeding success. Biol Conserv 41:1-10

Harris MP, Wanless S (1997) Breeding success, diet, and brood neglect in the kittiwake (Rissa tridactyla) over an 11-year period. ICES J Mar Sci 54:615-623

Heubeck M (2004) Black-legged kittiwake Rissa tridactyla. In: Mitchell PI, Newton SF, Ratcliffe N, Dunn TE (eds) Seabird populations of Britain and Ireland. T\&AD Poyser, London, p 277-290

Heubeck M, Mellor RM, Harvey PV (1997) Changes in the 
breeding distribution and numbers of Kittiwakes Rissa tridactyla around Unst, Shetland, and the presumed role of predation by Great Skuas Stercorarius skua. Seabird 19:12-21

Heubeck M, Mellor RM, Harvey PV, Mainwood AR, Riddington $R$ (1999) Estimating the population size and rate of decline of Kittiwakes Rissa tridactyla breeding in Shetland, 1981-97. Bird Study 46:48-61

ICES (2003) Report of the ICES Advisory Committee on Fishery Management. ICES Cooperative Research Report 261. International Council for the Exploration of the Sea, Copenhagen

Lewis S, Sherratt TN, Hamer KC, Wanless S (2001a) Evidence of intra-specific competition for food in a pelagic seabird. Nature 412:816-819

Lewis S, Wanless S, Wright PJ, Harris MP, Bull J, Elston DA (2001b) Diet and breeding performance of black-legged kittiwakes Rissa tridactyla at a North Sea colony. Mar Ecol Prog Ser 221:277-284

Lloyd C, Tasker ML, Partridge K (1991) The status of seabirds in Britain and Ireland. T\&AD Poyser, London

Macer CT (1966) Sand eels (Ammodytidae) in the southwestern North Sea; their biology and fishery. Her Majesty's Stationery Office, London

Mavor RA, Parsons M, Heubeck M, Pickerell G, Schmitt S (2003) Seabird numbers and breeding success in Britain and Ireland, 2002. UK Nature Conservation Report No. 27. Joint Nature Conservation Committee, Peterborough

Mitchell PI, Newton SF, Ratcliffe N, Dunn TE (eds) (2004) Seabird populations of Britain and Ireland. T\&AD Poyser, London

Montevecchi WA (1993) Birds as indicators of change in marine prey stocks. In: Furness RW, Greenwood JJD (eds) Birds as monitors of environmental change. Chapman \& Hall, London, p 217-266

Moss R, Wanless S, Harris MP (2002) How small Northern

Editorial responsibility: Otto Kinne (Editor-in-Chief), Oldendorf/Luhe, Germany
Gannet colonies grow faster then big ones. Waterbirds 25: 442-448

Munk P, Wright PJ, Pihl NJ (2002) Distribution of the early larval stages of cod, plaice and lesser sandeel across haline fronts in the North Sea. Est Coast Shelf Sci 55: 139-149

Pedersen SA, Lewy P, Wright P (1999) Assessments of the lesser sandeel (Ammodytes marinus) in the North Sea based on revised stock divisions. Fish Res 41:221-241

Proctor R, Wright PJ, Everitt A (1998) Modelling the transport of larval sandeels on the north west European shelf. Fish Oceanogr 7:347-354

Rindorf A, Wanless S, Harris MP (2000) Effects of sandeel availability on the reproductive output of seabirds. Mar Ecol Prog Ser 202:241-252

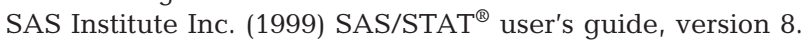
SAS Institute, Cary, NC

SAS Institute Inc. (2001) SAS/STAT ${ }^{\circledR}$ software: changes and enhancements, release 8.2. SAS Institute, Cary, NC

Swann RL, Harris MP, Aiton DG (1991) The diet of some young seabirds on Canna, 1981-90. Seabird 13:54-58

Turrell WR (1992) New hypotheses concerning the circulation of the northern North Sea and its relation to North Sea fish stock recruitment. ICES J Mar Sci 49:107-123

Wiens JA (1989) Spatial scaling in ecology. Funct Ecol 3: 385-397

Wright PJ (1996) Is there a conflict between sandeel fisheries and seabirds? A case study at Shetland. In: Greenstreet SPR, Tasker ML (eds) Aquatic predators and their prey. Fishing News Books, Oxford, p 154-165

Wright PJ, Bailey MC (1996) Timing of hatching in Ammodytes marinus from Shetland waters and its significance to early growth and survivorship. Mar Biol 126:143-152

Wright PJ, Jensen H, Tuck I (2000) The influence of sediment type on the distribution of the lesser sandeel, Ammodytes marinus. J Sea Res 44:243-256

Submitted: October 12, 2004; Accepted: May 3, 2005

Proofs received from author(s): August 30, 2005 